\title{
Reward of Management Practices for Employee Retention and Variable Payment to Public Institutions
}

Ugochukwu Paul Orajaka

To Link this Article: http://dx.doi.org/10.6007/IJARBSS/v11-i3/8929

DOI:10.6007/IJARBSS/v11-i3/8929

Received: 06 January 2021, Revised: 10 February 2021, Accepted: 25 February 2021

Published Online: 06 March 2021

In-Text Citation: (Orajaka, 2021)

To Cite this Article: Orajaka, U. P. (2021). Reward of Management Practices for Employee Retention and Variable Payment to Public Institutions. International Journal of Academic Research in Business and Social Sciences, 11(3), 212-225.

Copyright: (c) 2021 The Author(s)

Published by Human Resource Management Academic Research Society (www.hrmars.com)

This article is published under the Creative Commons Attribution (CC BY 4.0) license. Anyone may reproduce, distribute, translate and create derivative works of this article (for both commercial and non-commercial purposes), subject to full attribution to the original publication and authors. The full terms of this license may be seen

at: http://creativecommons.org/licences/by/4.0/legalcode

Vol. 11, No. 3, 2021, Pg. 212 - 225

Full Terms \& Conditions of access and use can be found at http://hrmars.com/index.php/pages/detail/publication-ethics 


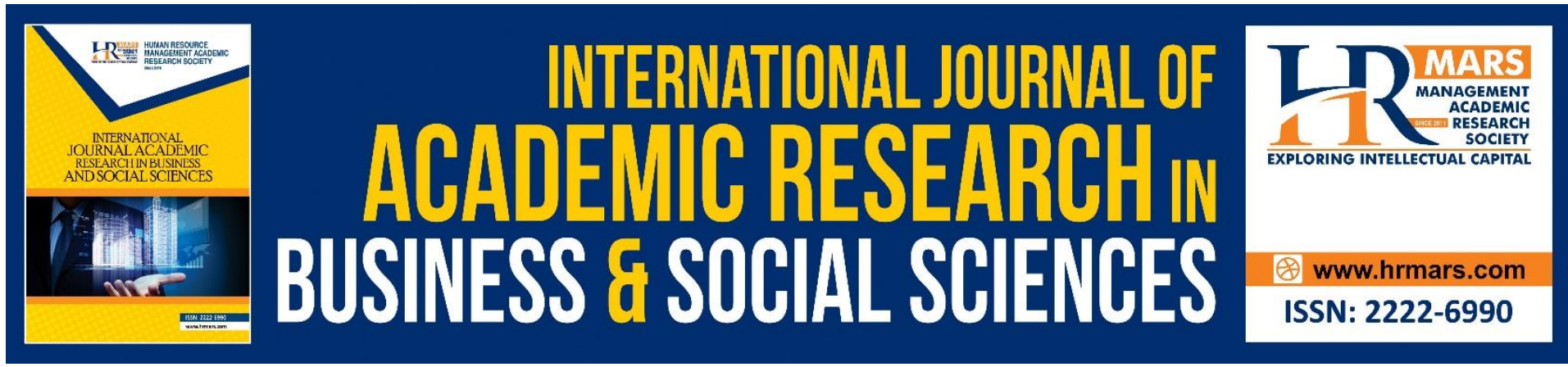

\title{
Reward of Management Practices for Employee Retention and Variable Payment to Public Institutions
}

\author{
Dr. Ugochukwu Paul Orajaka \\ Department of Entrepreneurship studies, Chukwuemeka Odumegwu Ojukwu University, \\ Igbariam Campus \\ Email: puorajaka@yahoo.com
}

\begin{abstract}
The study expressed the effect of variable payment and employee retention to the reward of Management performance in some selected organizations in south East Nigeria. The application of descriptive statistics, correlation tools and mean likert was employed to evaluate the significant relationship and coefficient of determination of the variables. However, the tools show that there is a strong positive relationship association between the variable payment and employee retention in public university. The analysis also shows that there is a strong positive significant relationship in the system. These results conclude that variable payment and employee retention has a strong positive effect to organizational performance in the study areas selected. The study is recommended for wider use applicable for the study areas, for academic purposes, for research and to understand the impact of variable payment and employee retention in organizational practices and its performances in public universities and beyond.
\end{abstract}

Keywords: Variable Payment, Employee Retention, Organization, Performance, Reward, Management Practices

\section{Introduction}

Reward forms part of the most important influencers of performance as it is a way of appreciating good performers. Markova and Ford (2011) opine that reward is one of the most practicable appreciation techniques and it is the main feature of human resource management that attracts and retain talented employees by motivating them to perform well. They are the most important techniques to keep employees motivated in accomplishing their tasks (Tuvei, Wanjere \& Mauyo, 2016). The findings of studies carried out to date indicate that rewards play a vital role in motivating employees so that they can perform creatively (Eisenberger \& Rhoades, 2001). Without a comprehensive and responsive reward strategy, companies will fail to maximize the potential of their employees (Parker \& Wright, 2001). Reward in organizations encompasses both financial and non-financial aspects, tangible and intangible aspects as opposed to the erroneous views that reward has to do with compensation alone. Rynes, Colbert and Brown (2002) explicate that when business owners think of reward systems, they typically put compensation at the top of the list. Reward 
systems are more than just compensation or monthly salaries (Bratton \& Gold, 2007). Reward systems are all of the monetary, non-monetary, and psychological payments that an organization provides for its employees (Turinawe, 2011). They include both of these incentives; but can also include awards and other types of recognition, promotions, reassignment, or other non-monetary bonuses too (Roshna \& Rohan, 2016). This is captured in the definition of reward management by Armstrong and Murlis (2007) which states that reward management refers to the strategies, policies, and processes that are required to ensure that the contribution of people in an organization is recognized by both non-financial and financial means. Every company needs a reward system for employees that address four key areas: compensation, benefits, recognition, and appreciation (Sarvadi, 2005). Reward has to do with what employees gets in exchange for their involvement in an organization, it is a form of positive reinforcement and motivation. It is that which an employee expects to get after putting in a days', months or years job in cash or in kind. Thompson (2002) avers that reward is the appreciation in cash or in kind given to employees for their contributions to a firm. Jiang et al., (2009) sees reward as a prize given to employees as an inducement towards their performance. It is the compensation which an employee receives from an establishment in exchange for the service offered by the employee (Jiang et al., 2009). Thus, reward is viewed as an exchange relationship between an employee or group of employees and an organization. Milkovich and Newman (2002) look at reward as an exchange strategy. They state that: "Employees may see reward as a return in exchange between their employer and themselves, as an entitlement for being an employee of the company, or as a reward for a job well done. Reward comes under what is called an employment exchange (Rynes \& Gerhart, 2000). Given the whole ambits of human resource management, hardly is any issue more vital, relevant, and crucial to an employee than what he gets in exchange for his labour and services to the organisation (Banjoko, 2006). Reward and its management are meant to complement the effort put forth by employees to propagate the wellbeing of the organization. Banjoko (2006) emphasize that reward management systems are meant to complement and reinforce business strategies. Armstrong, Brown and Reilly (2009) cited in Korir and Kipkebut (2016) state that reward management in competitive firms are designed in ways that make them to have accurate predictions on their current and future expected results. Mollahosseini et al. (2014) opine that reward management systems should be designed in a way that ensures maximum benefits for an organization. A well-designed reward system creates a sense of belonging among employees in an organization (Dalvi \& Ebrahimi, 2013). In the same way that reward management can necessitate positive performance like increase in employee commitment, improvement in job satisfaction and increase in the desire to be good organization ambassador, so also can reward if not properly management can lead to dampening of moral, reduced engagement in the organization and increase in the intention to leave the organization which seem to be the case in the three selected institutions in Ebonyi State University (EBSU), Ebonyi, Federal University of Technology Owerri (FUTO), Owerri and Nnamdi Azikiwe University, Awka, Anambra.It was observed that the performance of the non-teaching staff is not as it is supposed and this seems to be as a result of reward management issues. It is against this backdrop that this study seeks to identify the relationship existing between Variable pay and Employee Retention in the selected Public Institutions in the South East. 


\section{Literature Review Variable Pay}

Variable in ordinary parlance means being able to change or tending to deviate from normal recognized type. It could also mean alterable, flexible changeable and mutable. Going by this, variable pay is that pay that is flexible, changeable from the norm, being capable of being varied. Base pay which is what is entitled to the employees recently is losing its taste for pay that puts the level of performance into consideration. Traditional pay systems have been revised in response to changing business objectives and new forms of work organisation (Arrowsmith et al., 2010). As a result, performance pay is growing in importance (Dale, 2012).In this context, it is often stated that performance or variable pay is fundamental for competitive organizations (Appelbaum \& Shapiro, 1991; Appelbaum \& Shapiro, 1992). Variable pay is pay that puts the individual performance into consideration that as performance is met and exceeded, so also does pay increase and exceeds normal base pay. As observed by Heneman (2002), variable pay is a "method of rewarding employees for the results they achieve in organizations". In this context, individual or collective worker effort or performance is rewarded through incentive-based payments. Variable pay is the payment of cash to individuals in the form of performance pay or bonuses on the basis of their own performance or that of their team or organization (Armstrong \& Murlis, 2007). From the foregoing, it could be seen that variable pay could be divided into team-based variable pay and individual-based variable pay. However, within the context of this study, the focus is on individual-based variable pay. It is a pay strategy used to reward individuals for their performance and achievements in the organization. Miceli and Heneman (2000) state that organizations are increasingly using variable pay plans to reward employees for the results that they achieve. Variable pay does not only reward people for performing well but also tries to keep employees within the organization and attracts skilled ones for competitive performance. Eriksson and Villeval (2008) emphasize that variable pay links pay and performance but may also help firms to attract more productive employees. Employees' pay does not depend solely on the jobs they hold. Instead, organizations vary the amount paid according to differences in performance of the individual, group, or whole organization as well as differences in employee qualities such as seniority, educational levels, and skills (Milkovich \& Newman, 2008).

\section{Employee Retention}

Retaining employees in the organization is one of the most herculean tasks of Human Resource Management in organizations. This is because it is not easy to retain highly effective employees in a competitive market place. Njanja et al. (2013) posit that in a globalised world characterized by competition, access to latest technology and communication systems, and unfettered access to financial markets around the world, the ability to attract and retain qualitative workforce, as well as keep them highly motivated has become a great challenge. This challenge can successfully be navigated through an adequate reward system. Succinctly capturing this, Ejumudo (2011) opines that without adequate pay reward system, current employees are likely to leave and it will also be difficult to engage new people. Reward management is one of the strategies used by Human Resource Managers for attracting and retaining suitable employees as well as facilitating them to improve their performance through motivation and to comply with employment legislation and regulation (Njanja et. al, 2013). 
Reward management is aimed at not only attracting employees but also to retain them in the organization. Korir and Kipkebut (2016) posit that the reward management strategy of a company should be designed in a way that it attracts and retains the right employees by ensuring that there is a direct relationship between rewards and efforts. Reward management attracts and retains high-quality employees. The Centre for Effective Organizations observes that the ability of an organization to attract and retain employees depends mostly on its rewards. Reward management is one of the ways used by organizations for attracting and retaining suitable employees as well as facilitating them to improve their performance (Njanja, et. Al., 2013). Rewards management is used by organizations to attract, retain and motivate their employees. Remuneration does not simply compensate employees for their efforts- it also has an impact on the recruitment and retention of talented people (Milkovich \& Newman, 2001). Milkovich \& Newman (2001) opined that the success or failure of organizations hinges on the ability to attract, develop, retain, empower and reward a diverse array of appropriately skilled people. This is because there is a huge cost implication on employee attrition or turnover. It ranges from cost of recruitment, disruption of services and flows of activities, cost of training and lost time. Felps et al (2009) opine that as the global economy becomes increasingly knowledge-based, organizations that can successfully retain their human resources have an advantage over organizations that cannot. Shaw, Gupta and Delery (2005) state that indeed, a number of studies have shown that turnover negatively affects performance. For every employee who leaves a company, there are recruitment costs to find a replacement, lost productivity costs due to the vacated position, and training costs needed to train a new hire. For jobs that pay under $\$ 50,000$ per year, analysts have estimated that the cost of voluntary leaving per employee is approximately $20 \%$ of that employee's annual salary. However, when it comes to executive turnover, the cost can increase dramatically, costing up to $213 \%$ of that employee's salary. The longer the companies kept their employees; there would be no need for additional expenditure to train new employees. As such, employee retention was important to the long-term growth and success of the company. Retaining the best employees would ensure customer satisfaction and effective succession planning (Mello, 2006).

\section{Variable pay and Employee Retention}

Variable pay is used today by many organizations to enhance the performance of employee in organizations. Yeh et al. (2009) buttressed this point when they state that today variable pay systems are commonly implemented in organizations as a business strategy to improve performance of employees. Belfield and Marsden (2003) point out that the use of performance-related pay can enhance performance outcomes such as organisational citizenship behaviour. Armstrong (2012) opines that variable pay has the ability to make employees to form partnership with organization and to create the need for high levels of teamwork and collaboration between and among workers. Previous research has shown that for employees' whose performance is rewarded when they go "above and beyond", $90 \%$ are satisfied with their job, $88 \%$ are satisfied with the organisation and just $12 \%$ consider leaving the organisation. Amongst employees who say that their performance is not rewarded, $52 \%$ are satisfied with their jobs and $47 \%$ are satisfied with their organisation, and $36 \%$ seriously consider leaving. Tessema, Ready and Embaye (2013) in their paper concluded that both financial and non-financial rewards have a role in influencing job satisfaction, which ultimately impacts employee performance such as altruism. Turinawe (2011) found a significant positive relationship between the variables and employee performance. 


\section{Research Methodology \\ Research Design}

This study adopted a survey research design. This is because this study seeks to elicit data for analysis through the use of a questionnaire. A survey research design is such that collects data from people about variables through a questionnaire, observation or interview. Data were collected on employee recognition and job satisfaction.

\section{Area of Study}

This study was carried out in the South East Zone of Nigeria. The zone consists of five states which are Abia, Anambra, Ebonyi, Enugu, and Imo in their alphabetical order. The people found in these states are people of Igbo extractions and are mostly Christians and. The creation of Abia state was 1991 and its state capital is Umuahia. The creation of Anambra State also took place in 1991 with its state capital is in Awka. The capital of Ebonyi State is Abakaliki and its creation took place in 1996 while Enugu State was created in 1991 and the state capital is in Enugu town. Imo State was created in 1976 and its state capital is in Owerri.

\section{Population of the Study}

The population of the study consists of all the non-academic staff in the selected universities. The distribution of the population is given in the table below:

Table 1: Population Distribution

\begin{tabular}{lllc}
\hline S/N & STATE & ORGANIZATIONS & POPULATION \\
\hline 1 & Ebonyi & Ebonyi State University (EBSU) & 2009 \\
2 & Imo & $\begin{array}{l}\text { Federal University of Technology Owerri } \\
\text { (FUTO) Owerri }\end{array}$ & 2423 \\
& & Nnamdi Azikiwe University, Awka (UNIZIK) & 2979 \\
3 & Anambra & $\mathbf{7 4 1 1}$ \\
\hline
\end{tabular}

Source: Field Survey, 2020-12-03, Statistics Unit of the Personnel Department of the Studied Institutions.

Table 1 shows the distribution of the population among the three studied organization. From the table, it shows that EBSU has a total non-academic strength of 2009; FUTO has 2423 while UNIZIK has 2979 making it a total of 7411 staff.

\section{Sample Size Determination and Sampling Technique}

The sample size of the study was determined using Krejcie and Morgan (1970) formula. The formula is given thus:

$s=\frac{X^{2} N P(1-P)}{d^{2}(N-1)+X^{2} P(1-P)}$

Where: $S=$ Sample size; $X^{2}=$ Table value of chi-square for 1 degree of freedom @ 0.05\% confidence level (3.84); $N$ = population size (7411); $\mathrm{P}=$ population proportion (assumed to be 0.5 since this would provide the maximum sample size); $d$ = Degree of accuracy expressed as a proportion (0.05)

$S=\frac{3.84(7411)(0.5)(1-0.5)}{(0.05)^{2}(7411-1)+(3.84)(0.5)(1-0.5)}$ 
$S=\frac{7115}{18.525+0.96}=\frac{7115}{19.485}$

$S \cong 365$

Bowley's proportionate allocation formula was used in distributing the copies of the questionnaire in proportion to the population of the organizations studied. The formula is as follows:

$\mathrm{nh}=\frac{n N h}{N}$

Where: $\mathrm{n}=$ total sample size; $\mathrm{Nh}=$ Number of items in each stratum in the population; $\mathrm{N}=$ population size.

Table 2: Bowley's Allocation Formula

\begin{tabular}{llcc}
\hline S/N & \multicolumn{1}{c}{ ORGANIZATIONS } & $\begin{array}{c}\text { Applying } \\
\text { Formula }\end{array}$ & $\begin{array}{c}\text { No. } \\
\text { Allocated }\end{array}$ \\
\hline $\mathbf{1}$ & Ebonyi State University (EBSU) & $2009 \times 365 /$ & 99 \\
& & 7411 & \\
$\mathbf{2}$ & Federal University of Technology Owerri (FUTO) & $2423 \times 365 /$ & 119 \\
& Owerri & 7411 & 147 \\
3 & Nnamdi Azikiwe University, Awka (NAU) & $2979 \times 365 /$ & 365 \\
& & 7411 & \\
\hline
\end{tabular}

Source: Field Survey, 2020

Table 2 gives details on how the copies of the questionnaire were distributed to the studied higher institutions. A total of 99 copies were allocated to EBSU, 119 copies to FUTO and 147 copies to UNIZIK making it a total of 365.

\section{Sources of Data}

The sources of data for this study were both primary and secondary sources. Questionnaire instrument constitutes the primary source while journal articles and materials, textbooks and the internet constitute secondary sources.

\section{Description of Data Collection Instrument}

The data collection instrument was a five-point structured Likert questionnaire. The codes are as follows: Strongly Agree (5), Agree (4), Undecided (3), Disagree (2) and Strongly Disagree (1). The questionnaire contains eight parts with five questionnaire items each which made the total number of items in the questionnaire to be ten (10).

\section{Reliability of the Instrument}

The consistency level of the instrument is the key factor in survey research. Sequel to this, the instrument was subjected to Split-Half reliability technique to ascertain how consistent the instrument is in eliciting data using $20 \%$ (73 copies of the questionnaire) of the sample size in Enugu State University of Science and Technology. The result obtained is detailed in the reliability output below: 
Table 3: Reliability Statistic

\begin{tabular}{|c|c|c|c|}
\hline \multicolumn{4}{|c|}{ Reliability Statistics } \\
\hline \multirow[t]{5}{*}{ Cronbach's Alpha } & \multirow[t]{2}{*}{ Part 1} & Value & .872 \\
\hline & & $\begin{array}{l}\mathrm{N} \text { of } \\
\text { Items }\end{array}$ & $20^{a}$ \\
\hline & \multirow[t]{2}{*}{ Part 2} & Value & .881 \\
\hline & & $\begin{array}{l}\mathrm{N} \text { of } \\
\text { Items }\end{array}$ & $20^{\mathrm{b}}$ \\
\hline & \multicolumn{2}{|c|}{ Total $\mathrm{N}$ of Items } & 40 \\
\hline \multicolumn{3}{|c|}{ Correlation Between Forms } & .877 \\
\hline \multirow{2}{*}{$\begin{array}{c}\text { Spearman-Brown } \\
\text { Coefficient }\end{array}$} & \multicolumn{2}{|c|}{ Equal Length } & .934 \\
\hline & \multicolumn{2}{|c|}{ Unequal Length } & .934 \\
\hline \multicolumn{3}{|c|}{ Guttman Split-Half Coefficient } & .902 \\
\hline
\end{tabular}

Source: Field Survey, 2020

\section{Method of Data Analysis}

Data analysis was done through the use of Pearson's Product Moment Correlation Coefficient. This is because the objective is to determine the type of relationship and Pearson's Correlation helps in giving the direction of the relationship (positive or negative) and also the magnitude of relationship exiting between studied variables.

\section{Decision Rule}

The level of significance used is 0.05 , this guided the interpretation of correlation results to know whether the result is statistically significant or not. If the $p$-value obtained is less than 0.05 ( $p$-value $<0.05$ ), the alternate hypothesis will be accepted, but if the $p$-value is greater than 0.05 ( $p$-value $>0.05$ ), the null hypothesis will be accepted. For the interpretation of the strength of the relationship, table 4 below will b used.

Table 4: Correlation Interpretation Table

\begin{tabular}{cc}
\hline Value of coefficient & Relation between variables \\
\hline $0.70-1.00$ & Very strong Correlation \\
$0.50-0.69$ & Substantial Correlation \\
$0.30-0.49$ & Moderate Correlation \\
$0.10-0.29$ & Low Correlation \\
$0.01-0.09$ & Negligible Correlation \\
\hline
\end{tabular}

Source: Alwadael (2010)

To further test the statistical significance nature of the relationship, the study measured the calculated $r$ against the critical $r$, if the calculated $r$ is greater than the critical $r$, it means that the relationship is significant and thus, the hypothesis will be accepted, if otherwise, the hypothesis will be rejected.

\section{Research Question Four}

What is the relationship existing between Variable pay and Employee Retention in the selected Public Universities in the South East? 
Table 5: Distribution of Responses forVariable pay and Employee Retention

\begin{tabular}{|c|c|c|c|c|c|c|c|c|}
\hline $\mathrm{S} / \mathrm{N}$ & Questionnaire Items & $\begin{array}{l}\text { SA } \\
(5)\end{array}$ & $\begin{array}{c}A \\
(4)\end{array}$ & $\begin{array}{l}\text { UD } \\
\text { (3) }\end{array}$ & $\begin{array}{l}D \\
(2)\end{array}$ & $\begin{array}{l}\text { SD } \\
(1)\end{array}$ & Mean & Decision \\
\hline \multicolumn{9}{|c|}{ Variable pay } \\
\hline 1 & $\begin{array}{l}\text { People in my organization do not } \\
\text { receive the same pay as it varies } \\
\text { based on performance. }\end{array}$ & - & 34 & 49 & 117 & 116 & 2.00 & Reject \\
\hline 2 & $\begin{array}{l}\text { The reward we receive in my } \\
\text { organization is flexible in that it } \\
\text { depends on individual skill-set. }\end{array}$ & 12 & 23 & 39 & 242 & - & 2.38 & Reject \\
\hline 3 & $\begin{array}{l}\text { The better the performance of } \\
\text { people in my workplace, the } \\
\text { greater the reward they are likely } \\
\text { to receive. }\end{array}$ & - & 45 & 67 & 128 & 76 & 2.26 & Reject \\
\hline 4 & $\begin{array}{l}\text { The performance of employees are } \\
\text { not considered while rewarding in } \\
\text { my organization. }\end{array}$ & 121 & 94 & 12 & 89 & - & 3.78 & Accept \\
\hline 5 & $\begin{array}{l}\text { Everybody is paid according to } \\
\text { what he/she is supposed to receive } \\
\text { irrespective of your performance. }\end{array}$ & 161 & 121 & 22 & 10 & 2 & 4.36 & Accept \\
\hline \multicolumn{9}{|c|}{ Employee Retention } \\
\hline 6 & $\begin{array}{l}\text { I will stay long in my organization if } \\
\text { my skills are well appreciated. }\end{array}$ & 123 & 87 & 2 & 104 & - & 3.72 & Accept \\
\hline 7 & $\begin{array}{l}\text { I do not want to leave my } \\
\text { organisation because my } \\
\text { competencies are well appreciated } \\
\text { within my organization. }\end{array}$ & 56 & 78 & 12 & 90 & 80 & 2.81 & Reject \\
\hline 8 & $\begin{array}{l}\text { I will quit my job because my } \\
\text { efforts are not properly } \\
\text { acknowledged in my organization. }\end{array}$ & 89 & 101 & - & 121 & 5 & 3.47 & Accept \\
\hline 9 & $\begin{array}{l}\text { My organization will lose my } \\
\text { services once I get an opportunity } \\
\text { to leave to other organizations. }\end{array}$ & 101 & 57 & - & 67 & 91 & 3.03 & Accept \\
\hline 10 & $\begin{array}{l}\text { Leaving my firm does not appeal to } \\
\text { me as I am well rewarded here. }\end{array}$ & 19 & 98 & - & 178 & 21 & 2.73 & Reject \\
\hline
\end{tabular}

Source: Field Survey, 2020-12-03

Table 5 shows the distribution of responses and descriptive statistics for Variable pay and Employee Retention in the selected Public Universities in the South East. The mean of the individual questionnaire items was used to ascertain whether cumulatively, they agree to or reject a questionnaire item. The benchmark for acceptance is $3(5+4+3+2+1=15 \div 5=3)$. Starting with the independent variable (variable pay), the respondents rejected the notion that people in their organization do not receive the same pay as it varies based on performance with a mean of 2.00. They also rejected that the reward they receive in their organization is flexible in that it depends on individual skill-set with a mean of 2.38. On the same wavelength, they rejected that the better the performance of people in their workplace, the greater the reward they are likely to receive with a mean of 2.26. They, however, accepted 
that the performance of employees is not considered while rewarding in their organization with a mean of 3.78. They almost unanimously agreed that everybody is paid according to what he/she is supposed to receive irrespective of their performance with a mean of 4.36. In the dependent angle of this section, the respondents agreed that they will stay long in their organization if their skills are well appreciated with a mean of 3.72. They rejected that they do not want to leave their organisation because their competencies are well appreciated within their organization with a mean of 2.81. They agreed with a mean of 3.47 that they will quit their job because their efforts are not properly acknowledged in their organization. They also agreed that their organization will lose their services once they get an opportunity to leave to other organizations with a mean of 3.03. They rejected that leaving their firm does not appeal to them as they are well rewarded in it 2.73

\section{Hypotheses Test}

$\mathrm{H}_{1}$ : There is a significant relationship existing between Variable pay and Employee Retention in the selected Public Universities in the South East.

Table 6: Correlation Analysis for Variable pay and Employee Retention

\begin{tabular}{|cl|c|c|}
\hline & & VARPAY & EMPRET \\
\hline \multirow{2}{*}{ VARPAY } & Pearson & 1 & $.964^{* *}$ \\
& Correlation & 1 & .000 \\
& Sig. (2-tailed) & & 316 \\
& $\mathrm{~N}$ & 316 & 316 \\
& Pearson & $.964^{* *}$ & 1 \\
EMPRET & Correlation & .000 & \\
& Sig. (2-tailed) & 316 & 316 \\
\hline
\end{tabular}

Source: Field Survey, 2020

Where: VARPAY = Variable pay; EMPRET $=$ Employee Retention

Table 6 shows the correlation analysis carried out on Variable pay and Employee Retention in the selected Public Universities in the South East. The correlation coefficient obtained was .964 indicating a very strong positive relationship.

Table 7: Significance Test for Hypothesis Four

\begin{tabular}{ccccc}
\hline $\mathbf{N}$ & Cal. $\mathbf{r}$ & DF & Crit. r. & Remark \\
\hline 316 & .964 & 314 & 0.098 & Significant \\
\hline
\end{tabular}

Source: Field Survey, 2020-12-03

Table 7 shows the test of significance for hypothesis four. It showed that significance level of 0.05 and at 314 degrees of freedom, that the critical $r$ is 0.098 . Given that the calculated $r$ .964 is greater than the critical $r$ (cal. $r .964>$ crit. $r$ 0.098), the research hypothesis is therefore accepted

\section{Discussion of Findings}

The hypotheses of the study were empirically analysed through the use of correlation analysis and findings were made. From the first test of hypothesis, it was revealed that there is a 
significant relationship existing between variable pay and employee retention in the selected Public Universities in the South East of Nigeria. This entails that when pay or reward changes based on performance or lack of it, it will influence employee retention in the organization. Staff will love to stay in a place where they are sure that with better performance comes better pay and may be forced to work hard to get better pay if they do not work hard hitherto. Aligning with this study is that of Oyira, Regina, Nkamare, Lukpata1, Uwa1, Mbum (2015) who investigated the effect of reward system on health care workers performance and revealed that monetary reward had a positive impact on employees' performance. This signifies that monetary reward influences performance positively and a reward or monetary reward that varies based on performance keeps an employee in the organization. Also, Mphil, Ramzan, Zubair, Ali and Arslan (2014) who measured the impact of compensation on employee performance revealed that compensation has a positive impact on employee performance. Compensation here could be in terms of varying bonuses in such a way as to align with performance and that as it influences performance, so also does it influence turnover intentions. Simialrly, Sajuyigbe, Olaoye and Adeyemi (2013) who studied selected manufacturing companies in Ibadan, Oyo State, Nigeria to examine the impact of reward on employees' performance came out with a related result. The result of their study showed that reward dimensions jointly predict employees' performance, which accounted for $71 \%$ variance in performance.

\section{Summary of Findings}

a) There is a significant relationship existing between variable pay and employee retention in the selected Public Universities in the South East.

\section{cal. r .964 > crit. r 0.098}

\section{Conclusion}

The study concludes that variable payment has a significant positive relationship with employee retention in the studied Public University in the South East of Nigeria. This is owing to the fact that all the decomposed variables of variable pay and employee retention had significant positive relationships with each other as paired. The analysis concludes that there is a strong significant relationship between variable pay and employee retention in the system. The result is recommended for further wider use of the study, for academic purposes and for understanding of variable pay and employee retention to management performance and management practices in public Universities in South East, Nigeria. The researcher also recommends further studies in the area or reward management practices and management performance.

\section{References}

Appelbaum, S. H., \& Shapiro, B. T. (1991). Pay for Performance: Implementation of Individual and Group Plans, Journal of Management Development, 10(7), p. 30-40.

Appelbaum, S. H., \& Shapiro, B. T. (1992). Pay for Performance: Implementation of Individual and Group Plans, Management Decision, 30(6), p. 86-91.

Armstrong, M. (2009). Odměňování pracovníků. Praha: Grada Publishing, 126-132.

Armstrong, M. (2009).A Handbook of Human Resources Management Practice, $11^{\text {th }}$ ed, Kogan Page, London.

Armstrong, M. (2012). Armstrong's Handbook of Human Resource Management Practice. New York, NY: Kogan Page Publishers. 
Armstrong, M., \& Murlis, H. (2007). Reward Management: A Handbook of Remuneration Strategy and Practice. London, Kogan Page Limited.

Armstrong, M., Brown, D., \& Reilly, P. (2009). Increasing the Effectiveness of Reward Management. Brighton, Institute for Employment Studies.

Arrowsmith, J., Nicholaisen, H., Bechter, B., \& Nonell, R. (2010). The management of variable pay in European banking, The International Journal of Human Resource Management, 21(15), 2716-2740.

Banjoko, S. A. (2006). Managing Corporate Reward Systems. Ibadan: Pumark Nigeria Limited

Baptiste, N. R. (2008). Tightening the link between employee wellbeing at work and performance: A new dimension for HRM. Management Decision, 46(2), 284-309.

Belfield, R., \& Marsden, D. (2003). Performance pay, monitoring environments, and establishment performance, International Journal of Manpower, 24(4), p. 452-471.

Bratton, J., \& Gold, J. (2007). Human resource management: Theory and practice. (4th ed.). Basingstoke, Hampshire, UK: Palgrave Macmillan.

Caruth ,D., \& Handlogten, G., (2001). Managing Compensation (and understanding it too), A Handbook for the perplexed, Westport CT, Quorum Books.

Dale Olsen, H. (2012). Sickness absence, performance pay and teams, International Journal of Manpower, 33(3), 284-300.

Dalvi, M., \& Ebrahimi, H. (2013). Investigating the Effects of Reward on the Cooperation in the Sale and Marketing Department from Managers' Perspective (Isfahan Food industries Case Study). International Journal of Academic Research in Business and Social sciences, 3(1), 144-153.

Eisenberger, R., \& Rhoades, L. (2001). Incremental effect of reward on creativity. Journal of personality and social psychology, 81(4), 728-741.

Ejumudo, K. B. O. (2011). Performance Appraisal in the Delta State Civil Service. Journal of Management, 5(2), 21-28.

Eriksson, T. \& Villeval, M. C. (2008).Performance-pay, sorting and social motivation.Journal of Economic Behavior\& Organization, 68(2), p. 412-421.

Felps, W., Mitchell, T. R., Hekman, D. R., LEE, T. W., Holtom, B. S., \& Harman, W. S. (2009) Turnover Contagion: How Co-workers' Job Embeddedness and Job Search Behaviours Influence Quitting. Academy of Management Journal 52(3), 545-561.

Heneman, R. L. (2002). Strategic Reward Management: Design, Implementation, and Evaluation, Greenwich, CT: Information Age Publishing

Jiang, Z., Xiao, Q. I. H., \& Xiao, L. (2009). Total Rewards Strategy: A Human Resources Management Strategy Going with the Trend of the Times. International Journal of Business and Management, 4 (11), 177-184.

Korir, I., \& Kipkebut, D. (2016). The Effect of Reward Management on Employees Commitment in the Universities in Nakuru County-Kenya. Journal of Human Resource Management, 4(4), 37-48. doi: 10.11648/j.jhrm.20160404.12.

Markova, G., \& Ford, C. (2011). Is Money the Panacea? Rewards for Knowledge Workers. New York: John Wiley and Sons.

Mello, J. A. (2006). Strategic Human Resource Management. 2nd Edn., Thomson, Mason, $\mathrm{OH}$, 213-320.

Miceli, M. P., \& Heneman, R. L. (2000). Contextual Determinants of Variable Pay Plan Design: A Proposed Research Framework, Human Resource Management Review, 10(3), p. 289305.

Milkovich, G. T., \& Newman, J. M. (2008). Compensation (9th ed.), Boston: McGraw-Hill Irwin. 
Milkovich, G., \& Newman, J. (2002). Compensation, 7th ed. Homewood, IL. McGraw-Hill Higher Education.

Milkovich, G.,\& Newman, J. (2002). Compensation, 7th ed. Homewood, IL. McGraw-Hill Higher Education.

Mollahosseini, A., Kahnouji, K., Shamsiyeh, A., \& Kahnouji, A. (2014): An Assessment of the Relationship between Managers' Power Resources and Employees Commitment of Governmental Organizations in Rafsanjan South Eastern Iran. International Journal of Academic Research in Economics and Management Science, 3 (1), 244-256.

Mphil, A. H., Ramzan, M. R. Zubair, H. M., Ali, G. A., \& Arslan, M. A. (2014): Impact of Compensation on Employee Performance (Empirical Evidence from Banking Sector of Pakistan. International Journal of Business and Social Science, 5(2), 302-309.

Njanja, W. L., Maina, R. N., Kibet, L. K., \&Njagi, k. (2013): Effect of Reward on Employee Performance: A Case of Kenya Power and Lighting Company Ltd., Nakuru, Kenya. International Journal of Business and Management 8(21), 41-49.

Nnaji-Ihedinmah, N. C., \&Egbunike, F. C. (2015): Effect of Rewards on Employee Performance in Organizations: A Study of Selected Commercial Banks in Awka Metropolis. European Journal of Business and Management 7(4), 80-88.

Oyira,E. J., Regina, R., Nkamare, S. E., Lukpata, F. E., Uwa, S. L., \&Mbum, P. A. (2015): Effect of reward system among health care workers performance: a case study of university of Calabar teaching hospital Calabar, Nigeria. Journal of Hospital Administration, 4(3), 4553.

Parker, Owen, and Liz Wright (2001): "Pay and Employee Commitment: The Missing Link."Ivey Business Journal.

Roshna \& Rohan. (2016): Analyzing Role of Reward Management System on Managing Employee Performance Effectively: Study with reference to Co-operative Sugar factories in Pune, Maharashtra. Chronicle of the Neville Wadia Institute of Management Studies \& Research, 46-53.

Rynes, S. L., Colbert, A., \& Brown, K. G. (2002): HR professionals' beliefs about effective human resource practices: Correspondence between research and practice. Human Resource Management, 41, 149-174.

Rynes, S., \& Gerhart, B. (2000): Compensation in organizations: Current research and practice, San Francisco, CA: Jossey-Bass.

Sajuyigbe, A. S., Olaoye, B. O., \&Adeyemi, M. A. (2013): Impact of Reward on Employees Performance in a Selected Manufacturing Companies in Ibadan, Oyo State, Nigeria. International Journal of Arts and Commerce, 2(2), 27-32.

Sarvadi, P. (2005), The best way to reward employees. Solutions for growing Business. Retrieved February 27, 2005, from http:www.entrepreneur.com

Shaw, J. D. Gupta, N., \& Delery, J. E. (2005). Alternative conceptualizations of the relationship between voluntary turnover and organizational performance. Academy of Management Journal, 48, 50-68.

Tessema, M. T., Ready, K. J., \& Embaye, A. B. (2013): The Effects of Employee Recognition, Pay, and Benefits on Job Satisfaction: Cross Country Evidence. Journal of Business and Economics, 4(1), 1-12.

Thompson, P. (2002): Total Reward, Chartered Institute of Personnel and Development, London. 
Trevor, C. O., Gerhart, B., \& Boudreau, J. W. (1997): Voluntary turnover and job performance: Curvilinearity and the moderating influences of salary growth and promotions. Journal of Applied Psychology, 82, 44-61.

Turinawe, H. (2011). Reward Systems, Job Satisfaction, Organizational Commitment and Employee Performance in Public Higher Institutions of Learning in Uganda.

Tuvei, D., Wanjere, D., \& Mauyo, H. (2016): Influence of Intrinsic Rewards on Organizational Performance in Sugar Companies of Western Kenya.International Journal of Science and Technology, 6(10).

Yen, H. R., \& Niehoff, B. P. (2004): Organizational citizenship behaviours and organizational effectiveness: Examining relationships in Taiwanese banks. Journal of Applied Social Psychology, 34, (8), 1617-1637. 